\title{
CMEARTICLE
}

\section{Vaginal discharge: evaluation and management in primary care}

Michelle $\underline{\operatorname{Sim}}^{1}$, MBBS, Susan $\underline{\operatorname{Logan}}^{2}$, MD, FRCoG, Lay Hoon $\underline{\mathrm{Goh}}^{1}$, MMED, FCFP

\begin{abstract}
Miss Lim, a 26-year-old business executive, came to your clinic for vaginal discharge of over one week's duration. A month ago, she had been treated with one dose of oral fluconazole for a vaginal yeast infection and had seen symptomatic improvement. On this occasion, she reported the same symptoms of itch and vaginal discharge. This was her third episode in six months. She was sexually active with one stable male partner. She thought the yeast infection had recurred and requested the same treatment.
\end{abstract}

\section{WHAT IS ABNORMAL VAGINAL DISCHARGE?}

Vaginal complaints account for approximately 10 million primary care visits annually in the United States alone. ${ }^{(1)}$ It is the most common gynaecological complaint seen by primary care doctors, yet rates of misdiagnosis are high. Vaginal discharge may be a normal physiologic occurrence or a pathological manifestation. In Singapore, we are likely to be underdetecting the number of women with abnormal vaginal discharge in primary care, as it is often viewed as a taboo complaint or embarrassing in Asian cultures. ${ }^{(2)}$

\section{Normal vaginal discharge}

Normal physiological discharge changes with the menstrual cycle. The character of the discharge tends to be clearer with a stretchable consistency around ovulation, then may be thicker and slightly yellow during the luteal phase. Normal healthy discharge should not be associated with symptoms such as itching, redness and swelling, and does not have a strong odour. ${ }^{(3)}$ Vaginal discharge can increase during higher oestrogen states, such as ovulation, the luteal phase, puberty and pregnancy, and with oestrogenbased therapies such as combined hormonal contraception and hormone-replacement therapies. Normal vaginal discharge is found in $10 \%$ of those who present with vaginal discharge. ${ }^{(4)}$

\footnotetext{
Abnormal vaginal discharge

Abnormal vaginal discharge is characterised by a change in colour, consistency, volume or odour, and may be associated with symptoms such as itch, soreness, dysuria, pelvic pain, intermenstrual bleeding or postcoital bleeding.(5) An important follow-up question to ask is whether the vaginal discharge is significantly altered from the woman's usual pattern. ${ }^{(3)}$ If the vaginal discharge has a significant change in colour and odour, contains blood or causes itch or discomfort, it is less likely to be physiological in nature.
}

\section{WHAT CAUSES SHOULD BE CONSIDERED?}

Abnormal vaginal discharge is most commonly caused by infection. $70 \%$ of all causes are associated with bacterial vaginosis (BV), vulvovaginal candidiasis (VVC) or trichomoniasis (TV). ${ }^{(6)}$ Of the three causes mentioned, BV is the most common and accounts for up to $50 \%$ of all infections. ${ }^{(5,7)}$ Table I summarises the clinical features and management aspects of these three common causes.

Cervicitis is another important cause of vaginal discharge, with Chlamydia trachomatis and Neisseria gonorrhoeae being the most common pathogens isolated. Cervicitis should be suspected in sexually active women found to have purulent endocervical discharge and easily induced cervical bleeding. ${ }^{(8)}$

Non-infectious causes include atrophic vaginitis, contact dermatitis due to allergic or irritant causes, foreign body vaginitis (e.g. retained tampon or condom), cervical polyps, fistulas and genital tumours (e.g. tumours of the vulva, vagina, cervix, fallopian tube and endometrium). ${ }^{(3)}$

\section{A diagnostic aid to vaginal discharge}

Abnormal vaginal discharge can also be categorised into two broad categories: inflammatory and non-inflammatory. This dichotomy can help physicians narrow down the possible aetiology based on the physical signs.

Inflammatory vaginitis is often associated with physical examination findings such as erythema and oedema and the presence of polymorphonuclear neutrophils (PMNs) on microscopic examination. This is most commonly seen in TV and VVC, but can also be found in atrophic vaginitis, desquamative inflammatory vaginitis and multimucosal erosive disease (e.g. erosive lichen planus and pemphigus vulgaris). On the other hand, non-inflammatory conditions do not have the aforementioned signs and are not associated with PMNs on microscopy. BV is the most common example. ${ }^{(7)}$

${ }^{1}$ Department of Family Medicine, National University Health System, ${ }^{2}$ Department of Obstetrics \& Gynaecology, National University Hospital, Singapore 
Table I. Clinical features associated with the three most common causes of vaginal discharge..$^{(5,9)}$

\begin{tabular}{|c|c|c|c|}
\hline Feature & Bacterial vaginosis & Trichomoniasis & Vulvovaginal candidiasis \\
\hline \multirow[t]{3}{*}{ Symptoms } & Thin discharge, bubbly & Scanty to profuse or frothy yellow-green discharge & Thick white discharge \\
\hline & Fishy odour & Offensive odour & Non-offensive odour \\
\hline & No discomfort or itch & Vulval itch, dyspareunia, dysuria, discomfort & $\begin{array}{l}\text { Vulval itch, dyspareunia, } \\
\text { dysuria, discomfort }\end{array}$ \\
\hline Signs & No inflammation of vulva & Vulvitis and vaginitis; 'strawberry cervix' & $\begin{array}{l}\text { Vulval erythema, oedema, } \\
\text { fissuring, satellite lesions }\end{array}$ \\
\hline Vaginal pH & $>4.5$ & $>4.5$ & $<4.5$ \\
\hline Microscopy findings & Clue cells & Motile trichomonads & Yeast and pseudohyphae \\
\hline $\begin{array}{l}\text { Need for testing for } \\
\text { other STls }\end{array}$ & $\begin{array}{l}\text { Consider in woman with risk } \\
\text { factors for STI (Box 2). }\end{array}$ & $\begin{array}{l}\text { Yes. Trichomoniasis is associated with } 2-3 \text { times increased } \\
\text { risk of HIV. HIV and other STI testing should be performed. }\end{array}$ & No \\
\hline Need for retesting & No & $\begin{array}{l}\text { Yes. }{ }^{(9)} \text { Retesting is recommended in sexually active } \\
\text { women. Retesting can be performed as soon as } 28 \\
\text { days post treatment to within } 3 \text { months. }\end{array}$ & No \\
\hline $\begin{array}{l}\text { Need to treat sexual } \\
\text { partner }\end{array}$ & No & Yes & No \\
\hline
\end{tabular}

HIV: human immunodeficiency virus; STI: sexually transmitted infection

\section{WHAT CAN I DO IN MY PRACTICE?}

A good history should include the woman's last menstrual period, characterisation of the vaginal discharge, associated symptoms, and sexual, medical and drug history including recent antibiotic use and type of contraceptive use. One should also assess for the possibility of a foreign body in situ and if there was any surgery or instrumentation to the genital region recently. It should be standard practice to offer a vagina and speculum examination to all women presenting with vaginal discharge, unless the woman refuses or is a virgo intacta. ${ }^{(5)}$ If a woman has fever, lower abdominal pain or if an examination reveals lower abdominal tenderness, mucopurulent cervicitis or cervical excitation, one should consider upper genital tract pathology.

In most local primary care settings, an in-house microscope may not be available, and specimens of vaginal discharge for investigations must be sent to an external laboratory. If a lower genital tract infection is suspected, point-of-care testing can aid diagnosis based on the $\mathrm{pH}$ levels of the discharge. Sample vaginal secretions are obtained from the lateral vaginal walls using a swab and then applied to a narrow-range $\mathrm{pH}$ paper $(\mathrm{pH} \mathrm{4-7).} \mathrm{Vaginal}$ $\mathrm{pH}<4.5$ is suggestive of $\mathrm{VVC}$ and $\mathrm{pH}>4.5$ is suggestive of $\mathrm{BV}$ or TV. However, it is not possible to distinguish between BV and TV using the $\mathrm{pH}$ test alone. Narrowing of the likely diagnosis can hence be made using a combination of clinical history and physical signs, together with the $\mathrm{pH}$ findings. ${ }^{(5,7)}$

A high vaginal swab for microscopy (wet mount and Gram stain), culture and sensitivity should be considered to confirm the diagnosis if the woman has the following characteristics: chronic or recurrent symptoms (Box 1), symptoms that are not characteristic of $\mathrm{VVC}$ or $\mathrm{BV}$, postpartum state, post termination of pregnancy, and post instrumentation. ${ }^{(5)}$ In the latter three, these women should be referred back to their obstetrics and gynaecology (O\&G) specialist.

Pregnant women can have an exaggeration of physiological vaginal discharge and asymptomatic vaginal microbiome. If they present with abnormal vaginal discharge, they should
Box 1. Definitions of chronic and recurrent symptoms:

- Chronic vaginal infection is defined as a woman having continuous symptoms despite conventional treatment. - Recurrent vaginal infection is defined as a woman who is asymptomatic after treatment but subsequently has a recurrence of symptoms.

be referred back to their O\&G specialist for a review. In the tertiary care setting, pregnant women are antenatally screened for Group B Streptococcus, but colonisation would not be expected to cause vaginal discharge. Any further testing is only performed in cases of preterm premature rupture of membrane, threatened preterm labour or suspected sexually transmitted infections (STI).

\section{Treatment}

For VVC, the choice of treatment can be based on the woman's preference, with single-dose oral fluconazole being as effective as topical azoles. However, an exception should be made when the woman is pregnant and the treatment of choice is a topical azole, as oral fluconazole is contraindicated in pregnancy. For the treatment of BV in pregnancy, oral metronidazole or clindamycin can be used, and for TV in pregnancy, oral metronidazole or metronidazole and nystatin (flagylstatin) vaginal pessary. For breastfeeding mothers, oral metronidazole $400 \mathrm{mg}$ twice daily for seven days should be used instead of $2 \mathrm{~g}$ single high-dose metronidazole, which is not recommended for this group. Treatment of the three most common vaginal infections is detailed in Table II.

Women should be advised to avoid alcohol consumption during treatment for up to 24 hours after completion of metronidazole or 72 hours after completion of tinidazole to reduce the possibility of a disulfiram-like reaction. Women with TV should be told to abstain from sexual intercourse until treatment is completed and symptoms have resolved, as it is sexually transmissible. ${ }^{(3,9)}$ 
Table II. Treatment regimens for the three most common causes of vaginal discharge.*

\begin{tabular}{|c|c|c|c|}
\hline Treatment & Bacterial vaginosis & Trichomoniasis & Vulvovaginal candidiasis \\
\hline $\begin{array}{l}\text { Recommended } \\
\text { regimen }\end{array}$ & $\begin{array}{l}\text { - Metronidazole } 400 \mathrm{mg} \text { orally BD } \\
\text { for } 7 \text { days (\$) } \\
\text { - Treatment of sexual partners is } \\
\text { not recommended }\end{array}$ & $\begin{array}{l}\text { - Metronidazole } 2 \mathrm{~g} \text { orally, single dose }(\$) \text { or } \\
\text { tinidazole } 2 \mathrm{~g} \text { orally, single dose }(\$ \$) \\
\text { - Treat sexual partners }\end{array}$ & $\begin{array}{l}\text { - Intravaginal agent: clotrimazole } \\
100 \text { mg pessary intravaginally } \\
\text { daily for } 6 \text { days (\$) or oral agent: } \\
\text { fluconazole } 150 \mathrm{mg} \text { orally in a } \\
\text { single dose (\$) } \\
\text { •Treatment of sexual partners is not } \\
\text { recommended }\end{array}$ \\
\hline $\begin{array}{l}\text { Alternative } \\
\text { regimen }\end{array}$ & $\begin{array}{l}\text { Clindamycin } 300 \text { mg orally BD for } \\
7 \text { days (\$\$) or tinidazole } 2 \mathrm{~g} \text { orally } \\
\text { once daily for } 2 \text { days ( } \$ \$ \text { ) or } \\
\text { tinidazole } 1 \mathrm{~g} \text { orally once daily for } \\
5 \text { days }(\$ \$ \text { ) }\end{array}$ & Metronidazole $400 \mathrm{mg}$ orally BD for 7 days (\$) & - \\
\hline Pregnancy & $\begin{array}{l}\text { Metronidazole } 400 \text { mg orally BD } \\
\text { for } 7 \text { days }(\$) \text { or clindamycin } 300 \\
\text { mg orally BD for } 7 \text { days }(\$ \$)\end{array}$ & $\begin{array}{l}\text { Metronidazole } 2 \mathrm{~g} \text { orally, single dose at any } \\
\text { stage of pregnancy (\$) or metronidazole } \\
400 \text { mg orally BD for } 7 \text { days (\$) or } \\
\text { metronidazole and nystatin (flagystatin) } \\
\text { vaginal pessary every night for } 10 \text { nights }(\$ \$)\end{array}$ & $\begin{array}{l}\text { Clotrimazole } 100 \text { mg pessary } \\
\text { intravaginally daily for } 6 \text { days (\$) }\end{array}$ \\
\hline $\begin{array}{l}\text { Recurrent } \\
\text { infection }\end{array}$ & $\begin{array}{l}\text { - First recurrence: retrial of same } \\
\text { regimen or trial of an alternative } \\
\text { regimen } \\
\text { - Multiple recurrences: } \\
\text { monthly oral metronidazole } \\
2 \mathrm{~g} \text { administered with oral } \\
\text { fluconazole } 150 \mathrm{mg}(\$ \$-\$ \$)\end{array}$ & $\begin{array}{l}\text { - Differentiate chronic infection from } \\
\text { reinfection } \\
\text { - If metronidazole } 2 \mathrm{~g} \text { single dose fails, trial of } \\
\text { metronidazole, } 400 \mathrm{mg} \text { BD for } 7 \text { days }(\$) \\
\text { - If metronidazole } 400 \mathrm{mg} \mathrm{BD} \mathrm{for} 7 \text { days also } \\
\text { fails, trial of metronidazole }(\$) \text { or tinidazole } \\
(\$ \$ \$), 2 \mathrm{~g} \text { daily for } 7 \text { days } \\
\text { - If the above regimens fail, consider } \\
\text { susceptibility testing for metronidazole- } \\
\text { resistant trichomoniasis }\end{array}$ & $\begin{array}{l}\text { - To achieve mycologic cure: topical } \\
\text { azole therapy for } 7-14 \text { days ( } \$ \text { - } \$ \text { ) } \\
\text { or fluconazole } 150 \mathrm{mg} \text { orally every } \\
\text { third day for three doses (Days } 1,4 \\
\text { and } 7 \text { ) }(\$) \\
\text { - For maintenance: oral fluconazole } \\
\text { (100 mg, } 150 \mathrm{mg} \text { or } 200 \mathrm{mg} \text { ) weekly } \\
\text { for } 6 \text { months }(\$ \$ \text { ); consider topical } \\
\text { treatment intermittently if oral is } \\
\text { not feasible }\end{array}$ \\
\hline
\end{tabular}

*Taking into consideration our local context and with reference from the Centers for Disease Control and Prevention (CDC) guidelines. ${ }^{(9)}+$ Not identified by the CDC or British Association for Sexual Health and HIV, but used locally, as components are safe in pregnancy. \$: < SGD 5; \$\$: SGD 5-15; \$\$\$: > SGD 15; BD: twice daily

\section{Patient education}

Women should be advised to avoid tight-fitting synthetic clothing, local irritants such as perfumed products and soap gels, and vaginal douching. ${ }^{(3)}$ There is no clear and consistent evidence across currently published studies regarding the role of probiotics for vaginal health. ${ }^{(10)}$ The use of topical azole formulations can weaken latex condoms and diaphragms. This risk should be mentioned to the woman prior to starting these medications.

\section{Screening for sexually transmitted infections}

It is recommended to screen for STI in women who are diagnosed with TV. ${ }^{(9)}$ Women who are at high risk of $\mathrm{STI}^{(5)}$ (Box 2) should be offered STI screening regardless of the organism identified. STI screening should include testing for Chlamydia trachomatis, Neisseria gonorrhoeae and $\mathrm{TV}^{(5)}$ as well as blood investigations for HIV, syphilis and hepatitis B virus. For TV, all sexual partners should be concurrently treated and sexual intercourse avoided for at least one week until they and their partners have completed treatment and follow-up.

\section{Recurrence of vaginal infection}

A subgroup of women present with a recurrence of vaginal infection after the first treatment. This group is asymptomatic in between discrete attacks. The estimated recurrence rate in the

\section{Box 2. Risk factors for sexually transmitted infections (STI):}

- Aged $<25 \mathrm{yr}$

- New sexual partner in the last three months

- Two sexual partners in the last six months

- No usage of condoms

- Symptoms or STI in sexual partner

• History of STI

literature is $5 \%$ for VVC infection (commonly defined as four or more culture-proven episodes in a year), ${ }^{(9,11)} 12.5 \%-18.5 \%$ in $\mathrm{TV}^{(12)}$ and up to $50 \%$ for BV (also defined as three or more confirmed episodes using Amsel's criteria in a few studies) within a one-year period. ${ }^{(13)}$ However, these statistics have an inherent limitation due to a few reasons: varying definitions of what recurrence means, use of over-the-counter medications and frequent empirical treatment of vaginal infections without diagnostic confirmation by physicians.

It is important to identify potentially reversible factors that could predispose the woman to recurrent infections such as uncontrolled diabetes mellitus and immunosuppression. Women with a history of recurrent BV and who are keen on contraception should be advised to use hormonal methods of contraception rather than intrauterine devices that can increase colonisation and prevalence of $\mathrm{BV} \cdot{ }^{(14)}$ 
Box 3. Refer to a gynaecologist if the following conditions or diagnoses are present:

1. Recent instrumentation or surgery of the genital tract*

2. Retained foreign body

3. Cervical ectopy or polyps

4. Suspected tumour of the genital tract

5. Symptoms of upper genital infection such as fever and lower abdominal pain

6. Recurrent vulvovaginal candida infections

7. Pregnant woman with abnormal vaginal discharge

8. Failure of routine treatment strategies as chronic symptoms can be a mimic of a vulval skin or pain disorder

*Includes loop electrosurgical excision procedure, hysterosalpingography, dilation and curettage, hysteroscopy, termination of pregnancy/evacuation of retained products of conception, laparoscopy and major gynaecological operations

If standard treatment strategies fail or symptoms recur, a referral should be considered, as a fungal culture can be performed in hospital settings. Box 3 shows the indications for referral to a gynaecologist.

\section{TAKE HOME MESSAGES}

1. Vaginal discharge can be either a normal physiologic occurrence or a pathological manifestation. It is important to differentiate between the two during the clinical consultation. A history of a change from the usual pattern of vaginal discharge is an important differentiating factor and should be explored with the woman.

2. Inflammatory features such as erythema and oedema during the physical examination may be helpful in narrowing the causes of the vaginal discharge.

3. The use of narrow-spectrum $\mathrm{pH}$ paper as a point-ofcare tool, if available, can help with the assessment of vaginal infection. High vaginal swabs for microscopy (wet mount and Gram stain), culture and sensitivity should be considered in those with chronic or recurrent presentations.

4. STI testing is recommended in high-risk sexually active woman or those with TV.

5. Referral to a gynaecologist should be considered if there is a history of recent instrumentation or surgery of the genital tract, retained foreign body, cervical ectopy or polyp, or suspicion of tumour on examination; or in women with symptoms of upper genital tract infection or recurrent vulvovaginal candida infections, pregnant women with abnormal vaginal discharge, or women who have failed routine treatment strategies.
You examined Miss Lim and found white, curdy vaginal discharge that was not foul-smelling. In view of her previous episodes, you took a high vaginal swab and treated her empirically with a single dose of oral fluconazole $150 \mathrm{mg}$. She saw you again a few days later to review her results, which were positive for candidiasis. Her symptoms had since improved. She asked you if any medications could prevent recurrence. You explained that no supplements or medications have been proven to reduce vaginal infections. However, you advised her to avoid wearing tight-fitting synthetic clothing, using perfumed products and soap gels, and performing vaginal douching. You advised her to return to see you if the symptoms recur and not 'doctor-hop' or use over-the-counter treatments. Miss Lim agreed to the treatment plans and promised to return if the vaginal discharge recurs.

\section{REFERENCES}

1. Paavonen J, Brunham RC. Bacterial vaginosis and desquamative inflammatory vaginitis. N Engl J Med 2018; 379:2246-54.

2. Sumudrika Ilankoon IM, Evangeline Goonewardena CS, Fernandopulle R, Rasika Perera PP. Women's understanding and cultural practices related to vaginal discharge: a qualitative study. Nurs Midwifery Stud 2018; 7:74-80.

3. Singh K, ed. Integrated Approach to Obstetrics and Gynaecology. New Jersey: World Scientific, 2016.

4. Quan M. Vaginitis: diagnosis and management. Postgrad Med 2010; 122:117-27.

5. NHS Oxfordshire Clinical Commissioning Group. Investigation and Management of Vaginal Discharge in Adult Women [online]. Available at: https://www.ouh.nhs.uk/ microbiology/diagnostic-tests/atoz/documents/discharge.pdf. Accessed May 13, 2020.

6. Paladine HL, Desai UA. Vaginitis: diagnosis and treatment. Am Fam Physician 2018; 97:321-9.

7. Neal CM, Kus LH, Eckert LO, Peipert JF. Noncandidal vaginitis: a comprehensive approach to diagnosis and management. Am J Obstet Gynecol 2020; 222:114-22.

8. Rao VL, Mahmood T. Vaginal discharge. Obstet Gynaecol Reprod Med 2020; 30:11-8.

9. US Centers for Disease Control and Prevention. Diseases Characterized by Vaginal Discharge. In: 2015 Sexually Transmitted Diseases Treatment Guidelines. Available at: https://www.cdc.gov/std/tg2015/vaginal-discharge. htm. Accessed October 13, 2019.

10. Tan H, Fu Y, Yang C, Ma J. Effects of metronidazole combined probiotics over metronidazole alone for the treatment of bacterial vaginosis: a meta-analysis of randomized clinical trials. Arch Gynecol Obstet 2017; 295:1331-9.

11. Sherrard J. Management of recurrent/persistent vaginal infections. Prescriber $2012 ; 23: 12-6$.

12. Seña AC, Bachmann LH, Hobbs MM. Persistent and recurrent Trichomonas vaginalis infections: epidemiology, treatment and management considerations. Expert Rev Anti Infect Ther 2014; 12:673-85.

13. Faught BM, Reyes S. Characterization and treatment of recurrent bacterial vaginosis. J Womens Health (Larchmt) 2019; 28:1218-26.

14. Achilles SL, Austin MN, Meyn LA, et al. Impact of contraceptive initiation on vaginal microbiota. Am J Obstet Gynecol 2018; 218:622.e1-e10. 


\section{SINGAPORE MEDICAL COUNCIL CATEGORY 3B CME PROGRAMME} (Code SMJ 202006A)

1. A proportion of women have normal physiological vaginal discharge.

2. Vaginal discharge can vary with the menstrual cycle and tends to decrease during higher oestrogen states.

3. Vaginal discharge that has a significant change in colour and odour, contains blood, and causes itch or discomfort is more likely to be abnormal.

4. The most common cause of vaginal discharge is vaginal infections.

5. Vulvovaginal candidiasis (VVC) is the most common cause of vaginal infections.

6. Chlamydia trachomatis and Neisseria gonorrhoeae should be suspected in sexually active women with purulent endocervical discharge and easily induced cervical bleeding.

7. Inflammatory vaginitis is often associated with physical examination findings of erythema and oedema, and is commonly seen in VVC and trichomoniasis (TV).

8. A vagina and speculum examination should be offered to all women presenting with vaginal discharge, unless the woman refuses or is a virgo intacta, to look for signs of atrophic vaginitis, foreign body and tumour growths.

9. A simple point-of-care test that can aid diagnosis is a $\mathrm{pH}$ test of the discharge.

10. A vaginal $\mathrm{pH}<4.5$ is seen in VVC and TV.

11. TV is a sexually transmitted disease and sexual partners need to be treated.

12. Pregnant women with abnormal vaginal discharge should be referred back to their specialist for a review.

13. Topical azoles are as effective as a single dose of oral fluconazole in the treatment of VVC.

14. Both topical azoles and oral fluconazole can be used to treat VVC in pregnant women.

15. The use of topical azole formulations can weaken latex condoms and diaphragms.

16. Metronidazole can be used in the treatment of both bacterial vaginosis (BV) and TV and can be used for pregnant women as well.

17. Vaginal douching helps to reduce the frequency and amount of vaginal discharge.

18. There is evidence for the use of probiotics for vaginal health.

19. In those with TV or in high-risk sexually active woman, testing for sexually transmitted infection is recommended.

20. Women who have a history of recurrent BV and are keen on contraception should not use intrauterine devices.

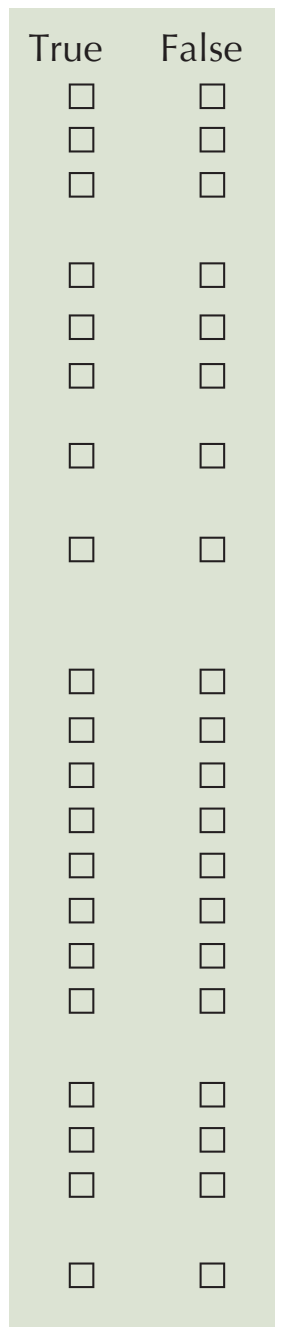

\section{Doctor's particulars:}

Name in full:

MCR no.:

Specialty:

Email:

\section{SUBMISSION INSTRUCTIONS}

Visit the SMJ website: http://www.smj.org.sg/current-issue and select the appropriate quiz. You will be redirected to the SMA login page.

For SMA member: (1) Log in with your username and password (if you do not know your password, please click on 'Forgot your password?'). (2) Select your answers for each quiz and click 'Submit'.

For non-SMA member: (1) Create an SMJ CME account, or log in with your SMJ CME username and password (for returning users). (2) Make payment of SGD 21.40 (inclusive of $7 \%$ GST) via PayPal to access this month's quizzes. (3) Select your answers for each quiz and click 'Submit'.

RESULTS:

(1) Answers will be published online in the SMJ August 2020 issue. (2) The MCR numbers of successful candidates will be posted online at the SMI website by 10 August 2020. (3) Passing mark is $60 \%$. No mark will be deducted for incorrect answers. (4) The SMJ editorial office will submit the list of successful candidates to the Singapore Medical Council. (5) One CME point is awarded for successful candidates. (6) SMC credits CME points according to the month of publication of the CME article (i.e. points awarded for a quiz published in the June 2020 issue will be credited for the month of June 2020, even if the deadline is in August 2020).

Deadline for submission (June 2020 SMJ 3B CME programme): 12 noon, 3 August 2020. 